\title{
EGFR NP_005219.2:p.A750_K754del
}

National Cancer Institute

\section{Source}

National Cancer Institute. EGFR NP 005219.2:p.A750 K754del. NCI Thesaurus. Code C98570.

A deletion of five amino acids from the epidermal growth factor receptor protein from the alanine at position 750 through the lysine at position 754 . 